\title{
Architectural Typology of Mamasa Traditional Graves, West Sulawesi, Indonesia
}

\author{
Mithen Lullulangi ${ }^{1, *}$, Armiwaty Tawani ${ }^{1}$, Rahmansah $^{2}$ \\ ${ }^{1}$ Department of Architecture, Faculty of Engineering, Universitas Negeri Makassar, Indonesia \\ ${ }^{2}$ Department of Civil Engineering Education, Faculty of Engineering, Universitas Negeri Makassar, Indonesia
}

Received July 28, 2020; Revised August 31, 2020; Accepted September 29, 2020

\section{Cite This Paper in the following Citation Styles}

(a): [1] Mithen Lullulangi, Armiwaty Tawani, Rahmansah, "Architectural Typology of Mamasa Traditional Graves, West Sulawesi, Indonesia," Civil Engineering and Architecture, Vol. 8, No. 5, pp. 832 - 837, 2020. DOI: 10.13189/cea.2020.080510.

(b): Mithen Lullulangi, Armiwaty Tawani, Rahmansah (2020). Architectural Typology of Mamasa Traditional Graves, West Sulawesi, Indonesia. Civil Engineering and Architecture, 8(5), 832 - 837. DOI: 10.13189/cea.2020.080510.

Copyright $\odot 2020$ by authors, all rights reserved. Authors agree that this article remains permanently open access under the terms of the Creative Commons Attribution License 4.0 International License

\begin{abstract}
Mamasa is one of the ethnic groups in West Sulawesi, which has a very unique culture, and the implementation of that culture is seen in the form of traditional architecture in the form of a house as a place to live, as well as other activities such as a traditional grave. This study determines the typology of traditional grave architecture in Mamasa, West Sulawesi, one of the traditional architectural products with high cultural value. This is a qualitative research with data collected through interviews, field observations, and documentation. The qualitative data analysis comprises of collection, presentation, reduction, and drawing conclusions. The results showed that the typology of traditional grave architecture in Mamasa emerged from the ancestral belief in Aluk Mappurondo, which consisted of 5 types, including a) Bangka-Bangka, b) Tedong-tedong, c) Ropi, d) Batutu or alang-alang, and e) Lokko'. The contribution of this research is to introduce one of the traditional architectural products that has high cultural value, as an object of research for scientists interested in traditional architecture or in the field of anthropology, and at the same time contribute in the field of tourism, as a cultural attraction that attracts both local tourists and foreign tourists, for the sake of increasing the country's foreign exchange in the field of Tourism.
\end{abstract}

Keywords Typology, Architecture, Grave, Traditional, Mamasa

\section{Introduction}

This study was conducted in collaboration with the Makassar State University and the Regional Planning and Development Agency (BAPPEDA) of Mamasa Regency to produce an inventory of the traditional architecture in Mamasa. The inventory includes houses, granaries, and graves, which are all archaeological objects of ancient relics with high cultural values, as well as the materials required for the planning and development of this area as a leading tourism destination in the West Sulawesi province.

Ambo, stated that studying the complex architecture of ancient graves does not only involve addressing tombstones; rather it also offers general knowledge concerning certain circumstances such as how the customs supported the concept of the cemetery, the engraved messages for pilgrims, choice of materials used, and so on [1].

The architectural development of graves in Mamasa is inseparable from civilization and culture, particularly matters relating to religion. Before the Dutch migrated to this area, the culture was entirely influenced by people's belief in Aluk Mappurondo (ancestral religion). According to Als Makatonan, Aluk Mappurondo involves four laws of life, namely: 1) Pa'totiboyongan or matters governing agriculture, 2) Pa'banne tauan or matters governing marriage, 3) $P a$ 'bisuan or decrees that regulate human life from birth until death, and 4) Pa'tomatean or matters relating to the death ceremony. Therefore, burial procedures and the architecture of the grave are also characterized by people's beliefs [2]. The death ceremony 
in the Mamasa area is referred to as Rambu solo (smoke coming down). Kaubi stated that this ritual disturbs the eyes, because it is associated with the tears of the grieving person, which flows in a downward direction similar to the flow of a river. This represents the journey of the departed soul to the spirit world (Pollondong) [3].

Therefore, ancient civilization enriched with rules rooted in the beliefs of the ancestors gave birth to various types of traditional grave typologies in the form of artifacts. Presently, they are still found in several places in Mamasa.

Ching reported that typology is interpreted as a systematic classification of a group of objects based on similar characteristics. However, there is also the tendency to classify elements based on compactness randomly, and visual features possessed [4]. Furthermore, Barliana stated that it is the study of types derived from the word Typos (Greek), which means impressions, images, or figures. Types are often used to describe the general shape, structure, or character of a particular form or object [5].

In numerous places and ethnic groups in Indonesia, the issue of grave typology related to tombstones is widely discussed as archaeological products. In ancient times, there was no tombstone because the dead were buried with large wooden coffins perforated on both sides. The various types of wooden coffins are also inseparable from the knowledge of mythology and the development of civilization, which has been passed down from generation to generation. Kaubi and Buijs, stated that according to mythological stories, the sky touches the earth at the northern hemisphere, while the sea serves as a mediator between the sky and the underworld [6]. This led to the historical background of the traditional ship-shaped houses in Mamasa, particularly the decorative art referred to as Badong, which is placed both in front and at the back. Buijs, reported that the exhibition of Badong reinforces the fact it is an ancient tradition compared to Tongkonan in Toraja [7]. It also related to the belief that their ancestors arrived by ship through a large sea that connects the sky and earth, which is strengthened by research on Chant for the Deceased conducted by Van der Veen [8].

Buijs, stated that the end of life is marked by the journey to Pollondong using ships (Bangka-Bangka) with various decorations similar to badong. [7] Van der Veen, reported that in Toraja, ship-shaped coffins, referred to as erong were used in the past. However, these coffins are still being used in Mamasa, and they are referred to as bangka-bangka [8]. Furthermore, Buijs, stated that the exhibition of small badong in coffins during the burial ceremony refers to the ancient belief that after death, people return to the spirit world through the sea. A sculpture that resembles a guardian or driver of the dead through the journey is placed on top of the badong [7]. This is based on the belief that when people die, they return to their initial place of origin and are regarded as a god. Buijs, defined burial as the preparation for the journey to heaven to become an ancestral god (membali dewata). Generally, the Mamasa people believe that when an individual dies, it is not considered to be dead. However, the person is assumed to be lao membali dewata or has transitioned a god that blesses and offers health to the family members in the world [9].

Whenever an individual dies, a series of ceremonies are in accordance with customary rules such as slaughtering chickens, pigs, or buffalo. This act is carried out to mark the person's final departure, and into the spirit world known as Indo 'Robo (Volkman) [10]. According to Mandadung, the slaughtered animals serves as a vehicle for the dead and shows the social status and wealth obtained, while on earth [11]. Furthermore, Buijs stated that the purpose of these sacrifices is not merely to provide guests food but also serve as dishes for the Lord of the Spirit World or lead to transcendent places in the afterlife [9].

The explanation of the experts offers an explicit description of the ancestral belief (Aluk Mappurondo) in Mamasa, concerning the journey of the dead to the spirit world (Pullondong), using ships (Bangka-Bangka). However, some people argued that the dead ride on the spirits of animals slaughtered during the Rambu Solo ceremony held. Both of these opinions have a strong basis, and presently, archaeological evidence is determined in the architectural typologies of the graves in Mamasa.

\section{Material and Methods}

The purpose of this study is to determine the architectural typology of traditional graves. This is a qualitative research, with data collected through interviews, field observations, and documentation. The data analysis technique is a qualitative review of data collection, presentation, reduction, and conclusions (Miles) [12].

\section{Research Result}

Several traditional villages in Mamasa Regency and community burial sites were visited, particularly the ancient graveyards, and various types of graves were examined as follows:

\section{Bangka-Banga}

In Mamasa or Limbong Kalua, the oldest type of grave consists of a corpse placed in perforated and covered wood either in the form of bangka-bangka (modeled as a boat) or tedong-tedong (shaped like a buffalo). According to the results from the interviews conducted on parents in the traditional villages visited, among others, Demmamala (75-year-old) from Buntuballa reported that the oldest grave models are Bangka-Bangka. Demmamala further stated that this type of grave had been in existence for long. Its age was estimated to be hundreds of years ago. This remark is supported by Demmaloga ( 85 years old) from Malabo reported that the grave model is old and no longer used. A similar opinion was expressed by the late $\mathrm{PH}$. 
Pualillin from Tawalian, and several other parents. None of the respondents interviewed, knew the exact age of this type of grave. Besides, both foreign and national works of literature were consulted, and none of them offered any valid data concerning the age of this grave. Even the literature written by Anggipurnamasari, and published by the Ministry of Education and Culture reports that the graves of Bangka-Bangka and Tedong-Tedong are hundreds of years old. The search results showed that this grave model was only found in Karassik Minanga Buntuballa, West Balla Village, in Paladan village, Sesena Padang sub-district, and Osango village, Mamasa sub-district and the condition was threatened with extinction. Fortunately, the one in Karassik Minanga of West Balla village has been turned into a tourist attraction and treated appropriately by the Department of Tourism [13].

This type of grave is made of large round or perforated logs in which the corpses are placed. The model is similar to a boat, and the cover is constructed of large wood as depicts the roof of a boat, the end of the grave is ornamented with buffalo head, while some are only decorated with small badong. These coffins are made of uru, a class I type of local wood that is durable and tends to last hundreds of years, assuming it is protected from the rains. This grave type is shown in Figure 1.

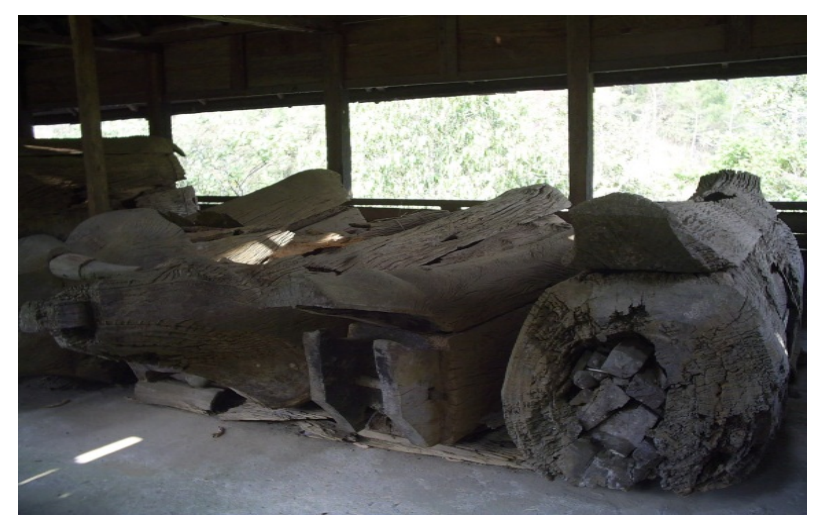

Source: Research Results

Figure 1. Types of Bangka-Bangka graves in Karassik Minanga Buntuballa

It is placed in Tadan, a kind of cottage specifically made for graves to protect it from being destroyed by the soil, which usually has a strong wooden base. In this modern era, the cement floor is made to ensure archaeological objects do not become extinct.

According to studies, several corpses were buried in one coffin, and when an old corpse decays and shrinks, a new one is added. Therefore, a Bangka-Bangka contains dozens of corpses, as shown in Figure 2.

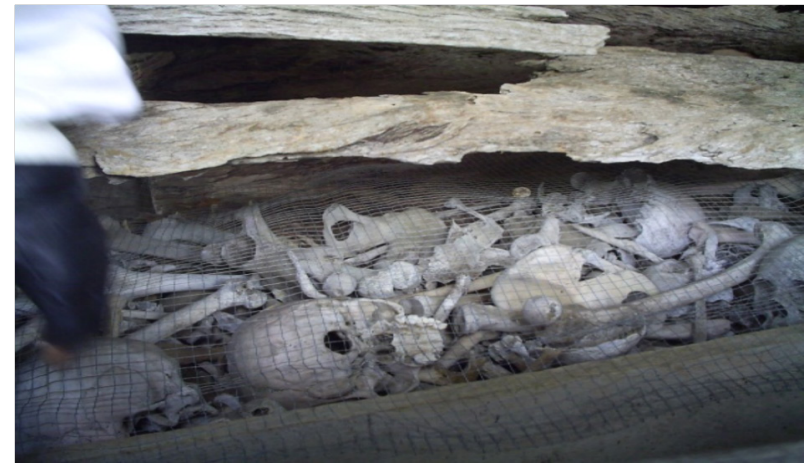

Source: Research Results

Figure 2. Weathered Bangka-bangka with many skulls indicates that one grave contains many corpses

\section{Tedong-Tedong}

The second oldest type of grave is Tedong-tedong. It is fabricated from strong uru logs, and the model has changed. It no longer resembles a boat; rather, it is shaped like a buffalo. The initial forms of these graves are similar to the Bangka-Bangka; however, due to civilization and an increased number of local geniuses, a leg was constructed to protect the grave from coming in direct contact with the ground to prevent weathering. Furthermore, it was inspired by the belief that the buffalo sacrificed at the funeral was the vehicle of the dead to Pollondong; therefore, local geniuses developed and fabricated horns and tail ornaments. The tomb is completed with its head resembling a buffalo, and it was referred to as Tedong-Tedong. There is no valid data to support the age of this graveyard. Anggipurnamasari, stated that the tomb in Minanga is a funeral center for the Kondo Sapata area, which comprises Lambanan in Mamasa sub-district, Tabang in Pana Sub-district and Rante Bulanan in Mambi Sub-district and it takes 2 (two) or 3 (three) days to arrive in Karassik Minanga Buntuballa at Balla District [13]. Furthermore, it was stated that the displacement of regions due to flooding that had hit the area was approximately 300 years ago, according to the Historical and Archaeological Data Collection Report of Mamasa Sub-district in 1986. Therefore, this age described only the current position, without stating when this type of grave became existent. Likewise, Mandadung, only reported that the tomb of Tedong-tedong in Karassik Minanga Buntuballa is hundreds of years old [14]. This type of grave is shown in Figure 3. 


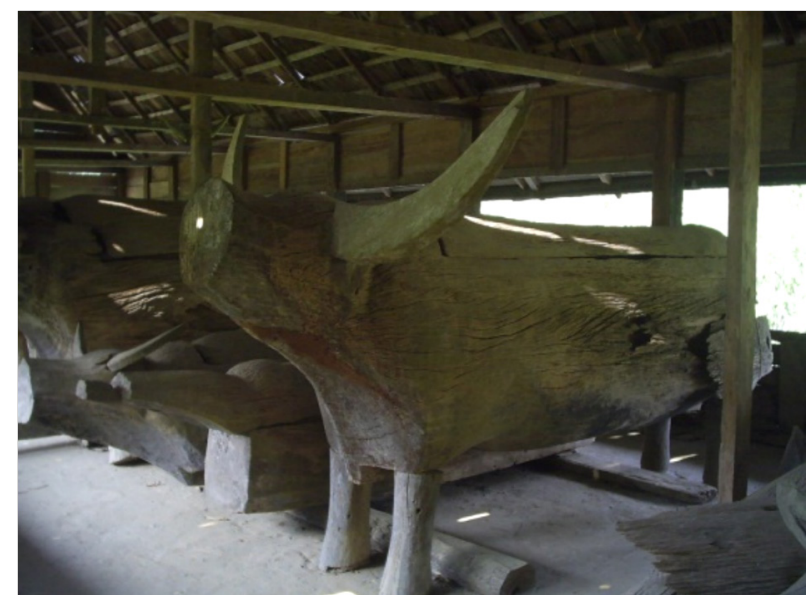

Source: Research Results

Figure 3. Tedong-tedong grave seen from the front shows the legs and head ornaments and horns like a buffalo that is standing.

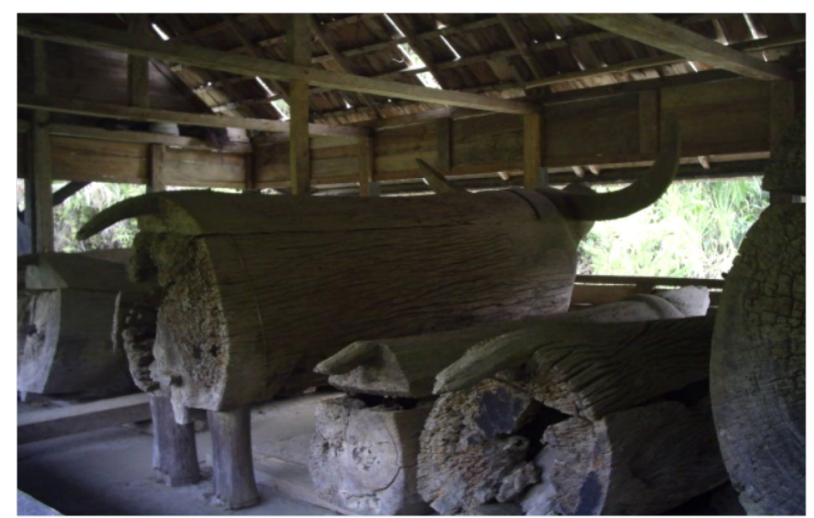

Source: Research Results

Figure 4. Tedong-tedong grave seen from behind shows the legs and tail ornaments clearly

\section{Ropi}

This type of grave is only found in Saloan village, Pana District. The material is made of uru logs that are perforated at the front in the direction of the fiber or annual wood dings and not at the top such as Bangka-Bangka and Tedong-Tedong. Therefore, it is perforated like a tunnel, with one end closed, and the other used as a door to place the corpse. None of the respondents were able to provide certain information about its existence. This type of grave is not as popular as the Bangka-Bangka and Tedong-Tedong, because only few studies have been conducted in this remote village. This type of grave is shown in Figure 5.

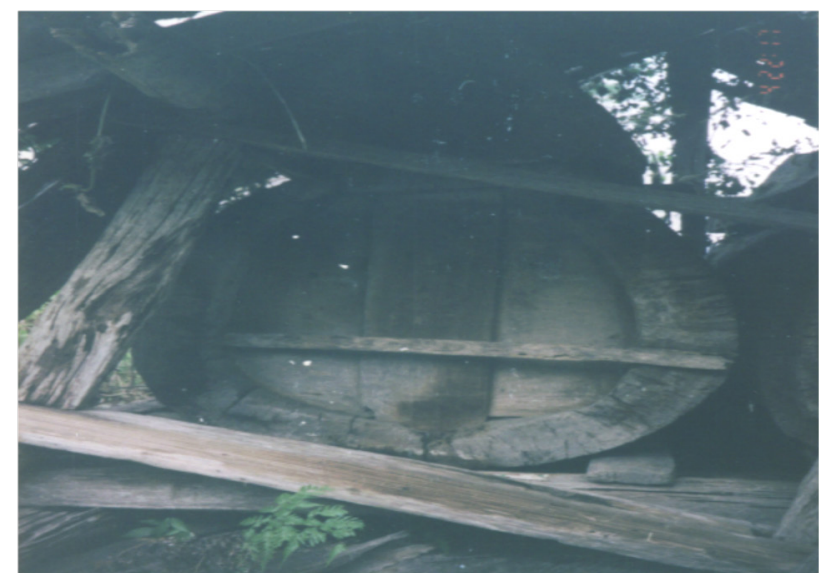

Source: Research Results

Figure 5. Grave of Ropi type made of round wood, which is perforated like a tunnel without ornamentation, and made a door to insert a corpse.

\section{Batutu}

Batutu is also another type of traditional graveyard made of uru wood. It is a small house with a door to place the corpses. Irrespective of the fact that it is considered a traditional grave, it is more modern than the previous types. It is found in almost every village in Mamasa, particularly the Eastern and Central regions except Mamuju in the West. Anggipurnamasari (2015) stated that Liang Batutu is made of wood and constructed in the form of a Mamasa traditional house. Some are black in color with corpses are wrapped in clothes and placed in the grave after the burial ceremonies. This tradition is common in Rante Buda, Lambanan, Pala, and Kariango. Examples of these graves are shown in Figure 6.

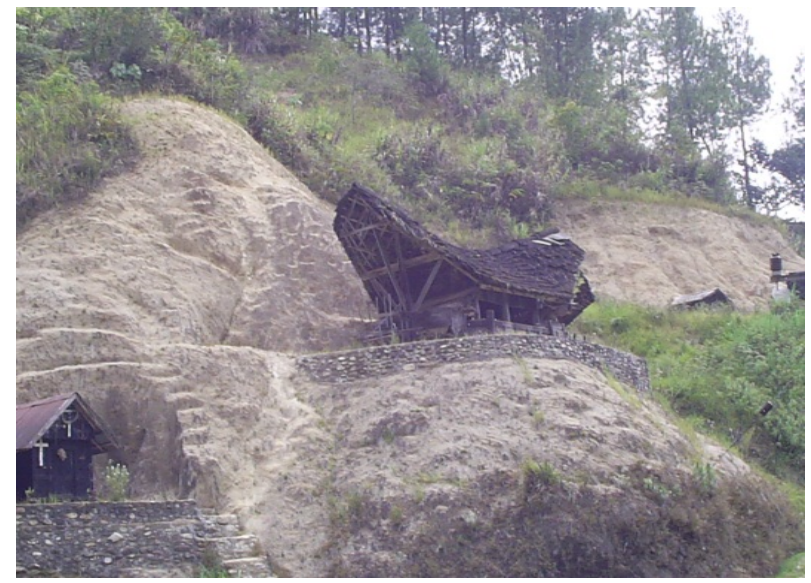

Source: Research Results

Figure 6. Grave Type of Batutu 
The Batutu structure is constructed from strong uru wood, with roof materials made of fern trunks. The proportions and ornaments resemble the decorations placed in front and at the back of the traditional Mamasa house, although they are smaller in size. This development is based on the increasing number of dead people and the fact that previous grave types no longer meet the demands of burial. Therefore, the people decided to construct a bigger grave to accommodate more bodies. This type of grave is usually owned by wealthy aristocratic families and is still used to date.

In some regions in Mamasa, such as Tabone, Messawa, Nosu, and Pana's areas (the southern part of Mamasa Regency), it is referred to as alang-alang. This type of grave has been modified and modern structural materials, namely cement, bricks, and roof covering from zinc or other industrial products, are presently used in its construction. An example is shown in the following figure.

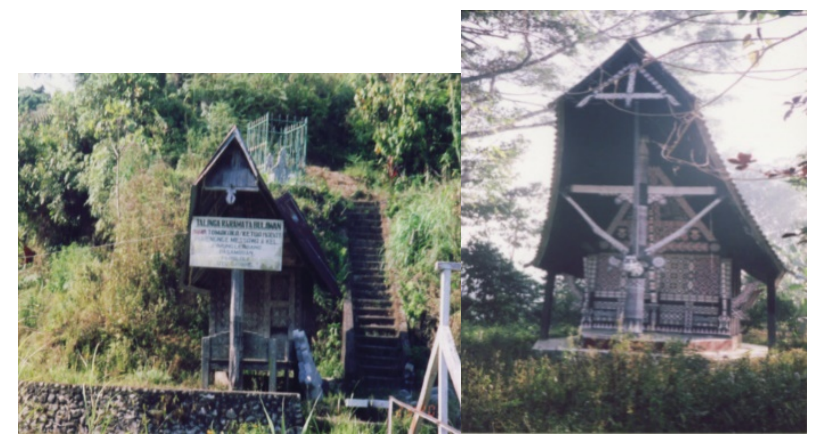

Source: Research Results

Figure 7. Graves of Batutu (alang-alang) type in Messawa and Tabone with roofs using modern structural materials, such as zinc roofs and metal roof tiles

\section{Lokko'}

This type of grave is a large artificial cave in the rocks which is used as a public cemetery, by a particular village. The entrance is usually as wide as the door of an ordinary house. However, there is a large room inside the cave, the center is used as the hallway, while the left and right hand side consist of porches in which the bodies are placed. Tadan, which is similar to a small house, is built in front of the door to protect it from the rains.

After this discovery, the Dutch introduced Christianity, and traders popularized Islamic teachings. Therefore, the burial procedures and architecture of the graves were heavily influenced by both religions. After that era, the dead Christians or Muslims are buried by digging a grave in the ground. However, most of them, particularly the Christians, believed that the form of burial does not contradict religion. Therefore, some of the people still use batutu, Alang-Alang or Lokko.

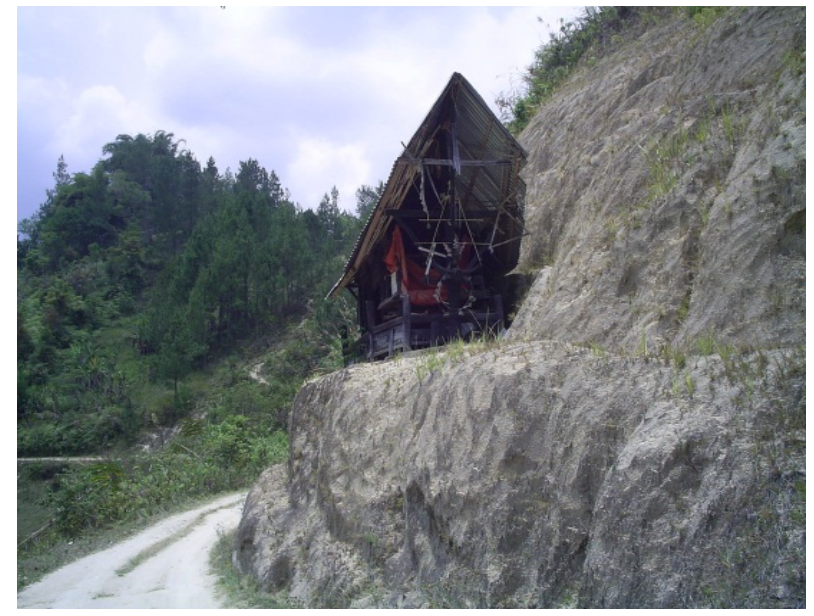

Source: Research Results

Figure 8. Tadan Lokko' in Orobua

\section{Discussion}

The teachings of aluk mappurondo showed that the ancestors of Mamasa arrived from a distant land, in ships or boats. This is a fundamental aspect of the story sengo-sengo padang written by Als Makatonan, which stated that the Mamasa ancestors (Pongkapadang) originated from Toraja Sa'dan, and met with the supposed Torije'ne from China, when their boat was stranded in Buntubulo, they got married, reproduced and died to become the ancestors of the Mamasa people [2]. According to the teachings of Aluk Mappurondo, when someone dies, the person is referred to as Loa Membali Dewata (Going to be a God). Buijs, stated that a person's burial prepares them for heaven to become ancestral gods (membali dewata), which according to mythological stories, is illustrated as Pollondong, a place of the spirit in the sky which is related to the sea in the northern hemisphere as reported by Kaubi and Buijs. The means of transportation are either a boat or a ship. Therefore, when people die, they are buried in a grave constructed in the form of a boat usually referred to as Bangka-Bangka a representative of the ship used by the spirits of the dead to travel to Pollondong. Therefore, the first traditional graves in this area are Bangka-Bangka. This is supported by ancestral beliefs and the opinions of experts that have conducted research in this area [9] [3] [6]. 
The initial architecture of the Bangka-Bangka graves enabled it to be placed on the surface of the ground in a protective hut called Tadan. However, it is eaten by termites and is eventually destroyed. This led to the need to construct poles or legs initiated by local geniuses, which was also supported by the belief that slaughtered animals are used as a means to Pollondong (Mandadung) [11]. Therefore, the shape of this bangka-bangka evolved into tedong-tedong equipped with ornamental variations, such as horns and tails. According to this research, it is the second type of grave in this area and is supported by several field facts, such as the discovery of several bangka-bangka whose ornamentation resemble the head of a buffalo, besides the small Badong (Buijs) [9].

Another grave type referred to as Ropi is found in Saloan. However, according to this study, it is a type of bangka-bangka grave, which does not possess an artistic touch; only the logs are perforated.

Furthermore, bangka-bangka and tedong-tedong have limited capacity. Due to an increase in death rate, the Batutu or alang-alang was developed. This type of grave also has limited capacity therefore mass graves such as an artificial cave in rocky hills referred to as Lokko' are constructed in each village. Presently, the traditional type of grave popularly used by the public is Batutu or alang-alang which has been modernized as private graves, besides Lokko'. Furthermore, the Muslim and some Christian communities have practiced the usual method of burying corpses in the ground.

\section{Conclusions}

Based on the results and discussion from this study, it can be concluded that the typology of the architecture of traditional graves in Mamasa, which relies on ancestral beliefs as stated by Aluk Mappurondo, consists of 5 types, namely: 1) Bangka-Bangka, 2) Tedong-tedong, 3) Ropi, 4) Batutu or alang-alang, and 5) Lokko.

\section{Acknowledgments}

The authors are grateful to the Government of Mamasa Regency through the Chairman of the Regional Planning and Development Agency (BAPPEDA) that collaborated and financed this research. The authors are also grateful to the Chairperson of the Department of Civil Engineering and Planning, Makassar State University, for facilitating this research and the entire Mamasa community.

\section{REFERENCES}

[1] Ambo, Asse Ajis. Pengetahuan Umum Tentang Ciri Khas Kompleks Makam Kuno di Aceh. 2019. https://www.ajnn.net/news/pengetahuan-umum-tentang-ciri -khas-kompleks-makam-kuno-di-aceh/index.html

[2] Als, Makatonan. Ada' Mappurondo. Hal. 2-4, dan 19. Kendari : Gepsutra. 1984.

[3] Kaubi, Jeanine. Rambu Solo', La fumee descend; La culte des morts chez les Toraja du sud. Page.347 and 402. Paris: Centre de Documentation et de Recherches sur Iasie du Sud-est et le Monde Insulindien. 1982.

[4] Ching, FDK. Architecture Form, Space and Order. New York: Van Nostrand Reinhold Company. 1979.

[5] Barliana, Syaom M. Tradisionalitas dan Modernitas Tipologi Arsitektur Masjid. Jurnal Dimensi Teknik Arsitektur Vol.32 No.2 Hal. 110 - 118. 2004.

[6] Buijs, Kees. Powers of blessing from the wilderness and from heaven; Structure and transformations in the religion of the Toraja in the Mamasa area of South Sulawesi. Page.60. Leiden : KITLV Press. 2006.

[7] Buijs, Kess. Tradisi Purba Rumah Toraja Mamasa Sulawesi Barat Banua sebagai Pusat Kuasa Berkat. Hal.100. Makassar: Penerbit Ininnawa. 2018.

[8] Veen, H. Van der.. The Sa'dan Toradja chant for the decceased. Page. 32. The Hague: [KITLV. Verhandelingen 45]. 1966.

[9] Buijs, Kees. Kuasa Berkat dari Belantara dan Langit Struktur dan Transformasi Agama Orang Toraja di Mamasa Sulawesi Barat. Hal. 92-93. Makassar: Penerbit Ininnawa. 2009.

[10] Volkman, Toby Alice. Feast of honor; Ritual and change in the Toraja highlands. Page. 103. Urbana: University of Illinois Press. 1985.

[11] Mandadung, Arianus. Budaya daerah Mamasa. Hal. 11. Ujung Pandang: n.n. 1999.

[12] Miles, Matthew B. Et al. Qualitative Data Analysis. Sage Publishing. 2014.

[13] Anggipurnamasari, Kompleks Makam Tedong Tedong Minanga di Kabupaten Mamasa Yang Terbuat Dari Kayu. 2015.

https://kebudayaan.kemdikbud.go.id/bpcbsulsel/kompleksmakam-tedong-tedong-minanga-di-kab-mamasa-yang-terbu at-dari-kayu/

[14] Mandadung, Arianus. Sejarah Pariwisata Mamasa dan Pola Perjalanan Wisata Kabupaten Mamasa. Hal.70. Mamasa : Lembaga Pelayanan Informasi Kepariwisataan 2017. 